\title{
Pedagogy Between Fear and Peace by Lennart Vriens,
}

Doctoral Dissertation, University of Utrecht, 1987.

Reviewed by

Wytze Brouwer

University of Alberta

This thesis, written in Dutch and therefore accessible to only a limited number of readers, is a call for a radical reorientation in pedagogy and education. The calling into question of the continued existence of humanity has created a fundamental uncertainty which has had demonstrable impact on the upbringing of children.

Vriens defines pedagogy as the dialectic between the value of being a child and the task of preparing the child for the future. In a fairly stable society this future-preparation is probably more determined by the present than any vision of the future because change in society has traditionally been slow. However, since 1945, the future has acquired a number of extra dimensions that have important implications for pedagogy. Not only is society faced with rapid change, but we also live under a cloud of uncertainty-facing the possible destruction of humanity.

It would seem self-evident that there should be a reorientation of pedagogy across the globe in the light of different future visions or future realities that lie before the children of today. The orientation that Vriens places before us is a pedagogy for peace. Such a coupling of pedagogy with peace is for Vriens an anthropological choice to make living in peace an explicit goal of pedagogy. One of the tasks Vriens undertakes in his thesis is to show that traditional pedagogies also incorporate, explicitly or implicitly, a view of humanity and a choice to nurture children in the light of such a vision. Vriens therefore searches for an anthropology of peace or an anthropology of hope on which a modern pedagogy can be built. Such an anthropological vision must be guided by a number of criteria such as:

Is there a pedagogical dimension to such a future vision?

Is there sufficient emphasis on political, humanistic, and moral values?

Is there room in such a vision for alternate opinions?

Phenomenology + Pedagogy Volume 71989 
In Chapter 3, Vriens shows in detail that the conditions for a classical or traditional pedagogy no longer exist in modern society. In a classical pedagogy, children were given the opportunity to develop a relatively harmonious relationship with their parents, in part because they had time to be children; they were not saddled with the problems of society or the uncertainty of existence. The conditions under which such a classical pedagogy could function included a guarantee of the children's feelings of security by the adults; the unquestioned continuity of the existence of society; the value of being a child living in a children's world, free from the concerns of adulthood; and room to develop, to grow, to experiment. Vriens suggests that after 1945 the conditions for such a pedagogical idyll no longer existed, that the fears and concerns of the adult world have intruded into the children's world. Even if such problems are not introduced explicitly into the world of the young, children sense fear and uncertainty in their parents, teachers, and peers. There is no longer a time to grow up insulated from the fears and concerns of society.

Vriens suggest that a new pedagogy has two essential tasks: (a) to encourage acceptance of the idea that all people share in the responsibility for the continuance of life on earth and for a society that makes such life possible; and (b) to convince people that raising children means raising children for a purpose, that pedagogy implies a meaning or purpose for life.

In Chapter 7, Vriens discusses the problematic relationship between pedagogy and the pursuit of peace. After all, peace is a concept with macrostructural and political dimensions, whereas pedagogy and education are much more closely bound to the personal level and small-group interactions. Moreover, there are within modern society a number of widely varying conceptions of peace education. In this chapter, Vriens reviews sympathetically the views of Bollnow, Beekman, Dasberg, Kern and Wittig, and Bloch on peace education based on hope. In Bollnow's vision, Vriens recognizes many of the building blocks for a pedagogy for peace but not a blueprint that gives the educator practical guidelines for peace education. Dasberg's writings underscore the need for a pedagogy of hope, in the absence of which pedagogy is judged to be impossible. In Bloch's writing, Vriens sees the characterization of hope as the "anticipatory consciousness of humanity," a hope that sets people "on the road toward a search of what is still to come and to a 
realization of what does not yet exist." Vriens then places this concept of hope in the Christian tradition of faith, hope, and love, the indissoluble triad of ideal Christian life. Vriens makes the case that even in a non-Christian setting, a love for the world and its people and a faith in humanity's ability to shape that future are interrelated with the type of hope that a pedagogy for peace promotes.

Vriens also outlines some changes in societal structures that should accompany peace education. These include a limitation of the sovereignty of nation states on the basis of the existence of international law and international structures; a concept of participatory democracy at societal levels at which people can still make a difference and affect social change; and a limitation of the macro-economies by creation of smaller scale relationships which make possible a coresponsibility of people for each other's well-being.

Vriens also suggests that a pedagogy of hope, which promotes a fairly radical alternative values orientation, needs nevertheless not signify a complete break with traditional pedagogy. A pedagogy for peace shares with traditional pedagogy the tasks of leading children into the adult world and into the meanings adults have given to that world. But a pedagogy for peace places greater emphasis on the responsibility of all humans to work for the continuance of this world and the changes required to achieve this. To the pedagogical criteria outlined by Langeveld, Vriens adds a fourth goal, the development of a responsible orientation toward a future so that life together with humanitarian values can be protected. Some of the values stressed by Vriens are concerns for social justice, solidarity with the poor, nonviolence, personal and international morality, and a concern for the earth's ecological balance. Such values form a basis for an implicit pedagogy for peace that Vriens would like to have permeate the whole curriculum rather than introducing a new subject-peace education-into the curriculum. Only at the higher levels can such an implicit peace education, formed by the family and the school, be enriched by the knowledge dimension in which the topics of war and peace, international affairs, economics, and ecology can be taught explicitly.

It is clear in the thesis that Vriens defines peace in a positive sense, not just as the absence of war and violence. The strong emphasis on social justice and development and on human rights indicates that peace education should not be concerned only with the visible manifestations of violence, but also with an examination of the conditions that lead to war. Vriens also accepts Galtung's notion of structural violence in which various 
societal structures can perpetuate inequalities and social injustices.

In Chapters 9 and 10 Vriens describes a Dutch primary school peace education project in which he explores children's cultures of war and peace. From about 11 years of age, children are acquainted with nuclear weapons and the possible destruction of life on earth. Younger children do know about war, and the boys especially appear to be rather fascinated by it. Young girls, however, show a critical stance toward war and violence and prefer to live in a peaceful world. Vriens relates how easy the boys find it to picture war, whereas they experience frustration in trying to picture peace. After the age of 11 , the ideas of boys and girls concerning war and peace appear to grow closer together. The play or game dimension of war begins to fall away in boys, and moral arguments and the recognition of nuclear war as total destruction begin to play a more important role. The boys begin to share the earlier developed girls' vision of themselves as victims in any future war.

In his thesis, Vriens demonstrates clearly that there is a great need for a reorientation of pedagogy toward a pedagogy of hope. Many children today do not sense in their upbringing a sense of purpose or meaning of existence that can give shape to their future. Parents and educators have become more cynical and unsure about the continued existence of humanity, and such concerns are being communicated to children. Vriens' vision of confronting young people, at appropriate times, with the responsibility which they carry for the continued existence of this world and the encouragement to accept such a responsibility and to work out its implications in their personal and social lives will help to give young people a sense of purpose that may have been absent for 40 years.

In a sense, Vriens' criticism that the work of Bollnow, Langeveld, and others has provided educators with many of the building blocks for a pedagogy of peace, but not a blueprint, also holds for Vriens. One sees a sketch, some images of how peace education may be introduced implicitly or explicitly into the schools. In the elementary school Peace Education Project, one recognizes one way in which the topics of war, peace, and conflict resolution can be creatively introduced in the schools. Many questions remain to be worked out, and in a sense research on a pedagogy of hope to restore a sense of purpose or meaning to life in a precarious world is in itself a labor of hope. A Pedagogy Between Fear and Peace is a thought-provoking thesis which should form the basis for further fruitful research in pedagogy and peace education. 